\title{
Productive performance, body chemical composition, and deposition of 42-day-old quail for meat subjected to quantitative dietary restriction
}

\section{Desempenho produtivo, composição e deposição química corporal aos 42 dias em codornas de corte submetidas à restrição alimentar quantitativa}

\author{
Daiane de Oliveira Grieser ${ }^{1 *}$; Simara Márcia Marcato ${ }^{2}$; Mariana Fátima \\ Zanon Ferreira ${ }^{3}$; Taciana Maria de Oliveira-Bruxel ${ }^{4}$; Vittor Zancanela ${ }^{5}$; \\ Mateus Silva Ferreira ${ }^{3}$; Caroline Espejo Stanquevis ${ }^{5}$; Eline Maria Finco ${ }^{5}$
}

\begin{abstract}
This study aimed to assess the effect of quantitative dietary restriction during refeeding on the performance, body chemical composition, and deposition, weight gain of organs and carcass parts of quails reared for meat (Coturnix coturnix coturnix). A total of 144 quails, between 11 to 42 days old, were distributed in a completely randomized design, $4 \times 2$ factorial scheme, at four levels of feed restriction (ad libitum, 30\%, 50\% and 70\% restrictions on the daily intake ad libitum) for both genders. Therefore, there was eight treatments with three replicates and six birds each. At the tenth day of age, the animals were housed in cages, where remained for four days under adaptation. Dietary restriction was applied between the days 15 and 35 while refeeding was carried out from day 36 to 42 . Compensatory weight gain (CWG), i.e. weight gain of organs and carcass parts, and feed efficiency (FE) were improved for quails under feed restriction. Fat (F), crude protein (CP), protein deposition rate (PDR) and fat in females (FDf) and carcass retained energy in females (CREf) increased linearly as restriction levels decreased. Maximum estimates of feed intake for males (MFIm), compensatory weight gain for males (CWGm) and females (CWGf), feed efficiency for males (FEm), protein deposition for males (PDm) and carcass retained energy in males (CREm) were obtained with restriction levels of 43.56\%, 30.56\%, 63.93\%, $62.63 \%, 80.25 \%, 1.94 \%$ and $09.34 \%$ if compared to ad libitum, respectively. As a result, we concluded that according to quantitative feed restriction level, significant increases in feed efficiency and body weight gain, as well as decreases in carcass fat throughout quail refeeding period. As for gender, given the existing sexual dimorphism, females lost greater body weight than males under dietary restriction, besides showing higher protein and fat gains in the carcass and an enhanced feed efficiency during refeeding.
\end{abstract}

Key words: Body chemical composition. Compensatory weight gain. Feeding levels. Organs. Carcass parts.

\footnotetext{
${ }^{1}$ Prof ${ }^{a}$, Departamento de Zootecnia, Universidade Estadual de Maringá, UEM, Maringá, PR, Brasil. E-mail: daianegrieser@gmail. com

2 Prof ${ }^{a}$, Programa de Pós-Graduação em Zootecnia, UEM, Maringá, PR, Brasil. E-mail: smmarcato@uem.br

3 Discentes, Curso de Mestrado no Programa de Pós-Graduação em Zootecnia, UEM, Maringá, PR, Brasil. E-mail: mariana_z3@ hotmailcom; mateusf.zoo@hotmailcom

${ }^{4}$ Prof $^{\mathrm{a}}$, Departamento de Zootecnia, Universidade Estadual do Oeste do Paraná, UNIOESTE, Marechal Candido Rondon, PR, Brasil. E-mail: tacideoliveira@hotmail.com

5 Discentes, Curso de Doutorado no Programa de Pós-Graduação Stricto sensu em Zootecnia, UEM, Maringá, PR, Brasil. E-mail: vitorzoo@hotmail.com; carol.stanquevis@gmail.com; emfinco@hotmail.com

* Author for correspondence
} 


\section{Resumo}

Neste estudo objetivou-se avaliar o efeito da restrição alimentar quantitativa sobre o desempenho, composição e deposição química corporal, ganho de peso de órgãos e partes da carcaça de codornas de corte (Coturnix coturnix coturnix) no período de realimentação. Foram utilizadas 144 codornas, de 11 a 42 dias de idade, distribuídas em delineamento inteiramente casualizado, em arranjo fatorial $4 \times 2$, com quatro níveis de restrição alimentar (ad libitum e restrição alimentar quantitativa de 30\%, $50 \%$ e $70 \%$ da ingestão diária dos animais ad libitum) e gênero, totalizando oito tratamentos, com três repetições e seis aves cada. Foram alojadas aos 11 dias de idade em gaiolas, permanecendo quatro dias em adaptação. Dos 15 aos 35 dias foi aplicada a restrição alimentar e a realimentação de 36 a 42 dias. O ganho de peso compensatório (GP), consequentemente de órgãos e partes da carcaça e a eficiência alimentar (EA) foram melhores em codornas submetidas à restrição alimentar. A gordura (GD), proteína bruta (PB) corporal, taxa de deposição de proteína (TDP) e gordura em fêmeas (TDGF) e energia retida na carcaça em fêmeas (ERCF) aumentaram linearmente à medida que diminuíram os níveis de restrição. As estimativas de máximo consumo de ração para machos (CRM) e fêmeas (CRF), ganho de peso compensatório para machos (GPM) e fêmeas (GPF), eficiência alimentar para machos (EAM), taxa de deposição de proteína para machos (TDPM) e energia retida na carcaça em machos (ERCM) foram obtidas com níveis de restrição alimentar de 43,56\%, 30,56\%, 63,93\%, 62,63\%, 80,25\%, 1,94\% e 9,34\% em comparação a ingestão ad libitum, respectivamente. Conclui-se que dependendo do nível de restrição alimentar quantitativa, ocorre melhora significativa na eficiência alimentar, aumenta o ganho de peso corporal e diminui a quantidade de gordura na carcaça no período de realimentação de codornas de corte. Já para gênero, devido ao dimorfismo sexual existente, as fêmeas perderam maior peso corporal do que os machos na restrição e apresentaram maiores ganhos de proteína e gordura na carcaça e melhor eficiência alimentar no período de realimentação.

Palavras-chave: Composição química corporal. Ganho de peso compensatório. Níveis de alimentação. Órgãos. Partes da carcaça.

\section{Introduction}

The European quail strain (Coturnix coturnix coturnix) is one the most used for meat production. These animals reach an adult weight between 200 and 300 g (DU PREEZ; SALES, 1997), and slaughtering at 42 days of age is recommended (ABREU et al., 2014). This strain is well known for its rapid body growth until 21 days of age; thereafter, weight gain starts to decrease since protein and water deposition rates are declined, followed by an increase in fat content in carcass and organs. Overall, significant differences are observed between genders regarding body weight and nutrient deposition rates in the carcass (DU PREEZ; SALES, 1997).

For birds, reducing feed supply in a given period (quantitative) or decreasing the amount of nutrients in the diet (qualitative) are techniques targeting at minimizing body fat accumulation and promote improvements in dietary efficiency (ROSA et al., 2000), which associated to a compensatory weight gain without compromising slaughter weight (PLAVINIK; HURWITZ, 1985). Another relevant factor of these techniques would be the reduction of feed costs, thus increasing the profitability of the production system, without compromising the carcass yield (LANA et al., 1999).

During dietary restriction, poultry growth rates are slowed down, being afterwards offset by refeeding (FONTANA et al., 1992). After a period of reduced growth, such increasing rates are defined as compensatory gain (YU et al., 1990). This procedure promotes a lower deposition of fat and larger of lean tissue in the carcass (OMOSEBI et al., 2014).

Such compensatory gain only occurs when animals are submitted to a short period of dietary restriction. Nevertheless, long intervals and severe levels of nutrient restriction can cause growth retardation or even permanent damages to the poultry, thus compromising a weight gain recovery 
during refeeding period (PLAVINIK; HURWITZ, 1985). For instance, a few studies have been carried out on broiler chickens and turkeys, which underwent feed restriction at an early growth stage without jeopardizing body weight at slaughter age (OSBOURN; WILSON, 1960; AUCKLAND; MORRIS, 1971).

Given the above, several studies have been performed focusing on determining the best levels of feed restriction, besides defining in which rearing phase it should be applied. These investigations also aim to evaluate further benefits from such dietary restrictions on animal production, with the purpose of improving carcass quality without affecting poultry productive and economic performance. Thus, this research was conducted to evaluate the effect of a quantitative feed restriction on productive performance, body chemical composition and deposition, weight gain of organs and carcass parts of male and female quail (Coturnix coturnix coturnix) during the refeeding phase (ad libitum).

\section{Material and Methods}

The experiment was carried out following the guidelines stated by the Committee of Ethics in Animal Experimentation of the State University of Maringá, in Brazil.

\section{Animals and diets}

One hundred and forty-four quails for meat (Coturnix coturnix coturnix), 72 males and 72 females, were conventionally reared from 1 to 10 days old, receiving water and feed ad libitum. Thereafter, the animals were divided into boxes lined with rice straw where remained from 11 to 42 days of age for the experiment period.

The experimental design was a completely randomized, in a $4 \times 2$ factorial scheme consisted of four feeding levels and two genders, totalling 8 treatments with three replicates containing six quails each. At 11 days of age, the birds were housed in galvanized wire cages, which was considered an experimental unit.

The first four days consisted of an adaptation period to the experimental cages, within which birds received feed ad libitum; yet water was supplied freely throughout the entire experiment. From 15 to 35 days of age, the animals underwent four feeding levels, which were ad libitum and quantitative dietary restrictions (DR) of $30 \%, 50 \%$ and $70 \%$ of the total consumed daily for each animal. These restriction levels were estimated based on ad libitum consumption measured the previous day; therefore, all units were daily checked. Later, from 36 to 42 days of age, a refeeding phase started, that is, feedstuff was provided ad libitum for all treatments.

Feeds were formulated based on corn and soy bran, considering the values of feed chemical composition according to Rostagno et al. (2011), in order to meet quail nutritional requirements at each rearing phase (Table 1). 
Table 1. Percent chemical and energetic composition of the feeds for quails in early growth (1 to 14 days of age) and final growth (15 to 42 days of age).

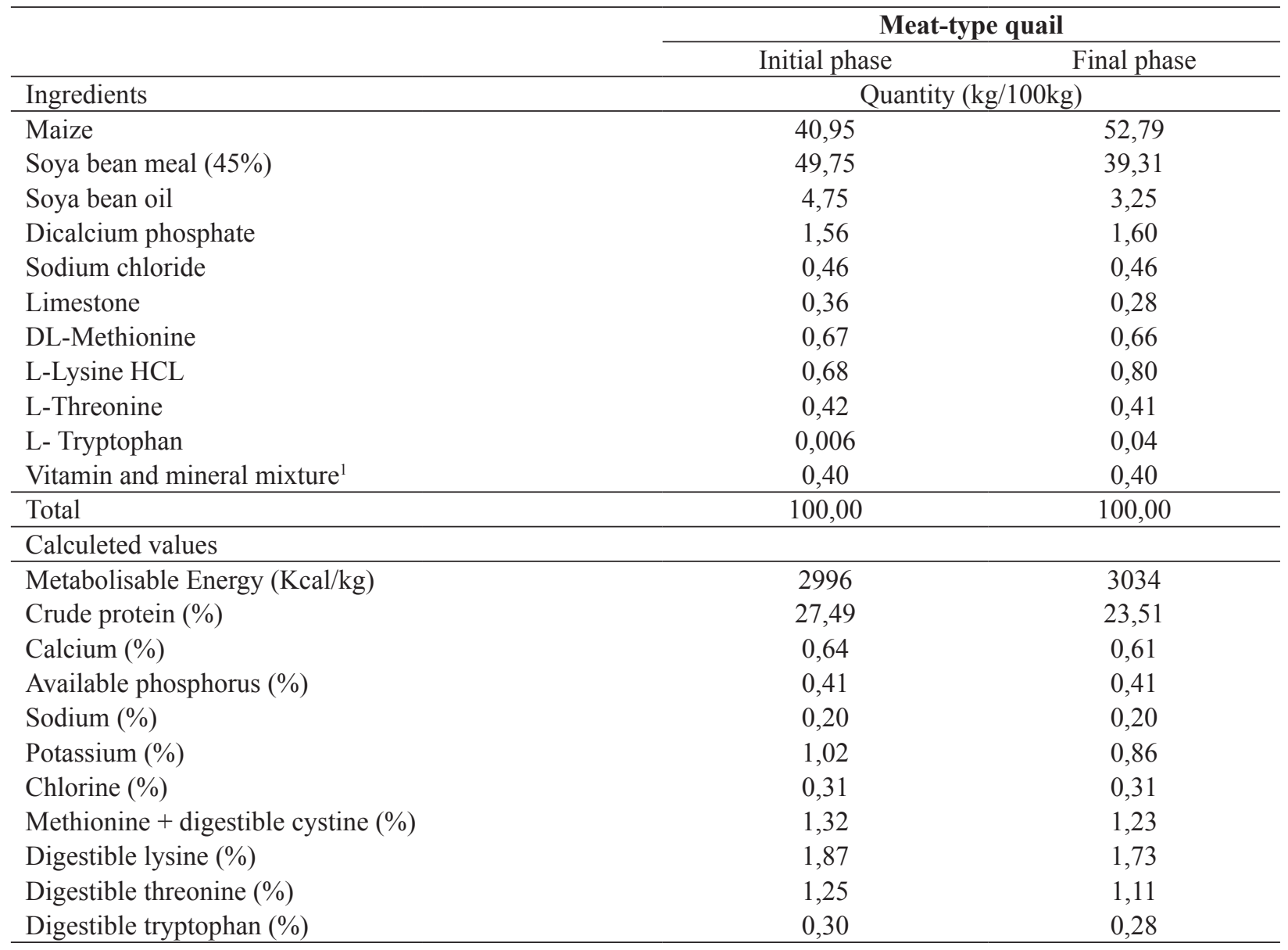

${ }^{1}$ Mineral-vitamin mix (replacement levels per kg of product); Vit. A - 4,500,000 IU; Vit. D3 - 1250,000 IU; Vit. E - 4,000 mg; Vit. B1 = 278 mg; Vit. B2 - 2,000 mg; Vit. B6 - 525 mg; Vit. B12 - 5,000 mcg; Vit. K3 = 1,007 mg; Calcium Pantothenate - 4,000 mg; Niacin - 10,000 mg; Choline - 140,000 mg; Antioxidant - 5,000 mg; Zinc - 31,500 mg; Iron - 24,500 mg; Manganese - 38,750 mg; Copper - 7,656 mg; Cobalt - 100 mg; Iodine - 484 mg; Selenium - 127 mg; 2 BHT (Butyl Hydroxy Toluene).

\section{Evaluation of performance}

The quails were weighed at 36 and 42 days of age and, simultaneously with this period, experimental feed provided to the animals and respective leftovers were weighed for determination of weight gains (being compensatory for treatments under feed restrictions $-30,50$ and $70 \%$ ), feed consumption (g) and food efficiency (\%). The weight gain was determined by the difference between final (42 days of age) and initial (36 days of age) weights of each experimental unit. Yet feed efficiency was estimated by the relationship between the average weight gain per bird in one replication and the average feed intake per bird.

\section{Weighing of organs and carcass parts}

Organs and carcass parts of one animal per replication were weighed at the beginning and at the end of refeeding (36 and 42 days of age). Birds were selected based on mean weight $( \pm 5 \%)$ of each experimental unit. After selection, the animals fasted for six hours for posterior weighing. Next, they underwent electrical stunning and further occipital bone displacement apart from the atlas bone. After bleeding, birds were scalded $\left(53-55^{\circ} \mathrm{C}\right)$ for 10 seconds, manually plucked, eviscerated by abdominal incision, and the organs were removed for weighing. The following organs were weighed: heart, liver, small intestine, gizzard, both wings 
together, legs and leg quarters, back and chest. In addition, the length of the small intestine was measured by means of a measuring tape.

\section{Body chemical composition and deposition}

The chemical composition of nutrients in quail carcasses was determined by a method described by Sakomura and Rostagno (2007), slaughtering one bird per repetition at 36 and 42 days of age. Prior to slaughter, animals were selected by the mean weight $( \pm 5 \%)$ of each experimental unit, identified with numbered plastic rings attached to the left foot. Then, they were submitted to six hours of fasting for complete emptying of the gastrointestinal tract. Subsequently, we performed the weighing of animals, submitting them to electrical stunning and further occipital bone displacement from the atlas bone.

After slaughter, the carcasses with feathers, viscera, feet, and head were frozen and then ground in an industrial meat grinder. Afterwards, the samples were homogenized, weighed and taken to a forced ventilation oven at $55^{\circ} \mathrm{C}$, where remained for 72 hours for a pre-drying. Later, they were weighed, ground in a knife-type mill and transferred to the laboratory for analytical determinations. Dry matter (DM), crude protein (CP), ethereal extract (EE) and mineral matter (MM) were evaluated. The methods for the aforementioned analyses are detailed in the AOAC (1990).

We used the methods described by Fraga et al. (2008) for estimations regarding protein and fat deposition rates ( $\mathrm{g} /$ day), protein deposition efficiency ( $g$ ) and carcass-retained energy (CRE, in kcal/ day). For CRE, the equation proposed by Sakomura (2004) was employed where the estimated energy values were 5.66 for protein and 9.37 for fat $(\mathrm{kcal} / \mathrm{g})$.

\section{Statistics}

Parameters investigated here were analyzed by means of SAS statistical software version 8.2
(SAS, 2001). The data were subjected to analysis of variance and subsequent polynomial regression $(\mathrm{p}<0.05)$ and, when factors interacted, a split analysis and linear regression were performed $(\mathrm{p}<0.05)$.

\section{Results}

\section{Poultry performance}

The levels of dietary restriction (DR) showed significant interaction $(p<0.05)$ among each other and between genders for the parameters feed consumption (FC), weight gain (WG) and feed efficiency (FE). The interaction points out that the DR levels and gender acted independently on poultry performance during refeeding (36 to 42 days of age).

There was a quadratic effect $(\mathrm{p}<0.05)$ for feed intake by males (MFIm) and females (MFIf), compensatory weight gain in males (CWGm) and females (CWGf) as well as feed efficiency for males (FEm) during refeeding (36 to 42 days of age), due to dietary restriction levels between 15 and 35 days of age. Female feeding efficiency (FEf) showed a linear behaviour, as shown in Table 2 .

The maximum estimates MFIm (206.75 g), MFIf (232.84 g), CWGm (70.63g), CWGf (77.90g) and FEm (38.29\%) were reached under restriction levels of $43.56 \%, 30.56 \%, 63.93 \%, 62.63 \%$ and $80.25 \%$ of ad libitum feeding, respectively (Figure 1).

Females submitted to $70 \%$ feed restriction showed the best result for FE, from which lower values of DR provided a decrease in FEf, because of a significant linear behaviour $(\mathrm{p}<0.05)$.

At this stage, the results of quail performance indicated that birds under no dietary restriction had lower feed consumption if compared to those previously submitted to certain restriction levels. The higher the restriction to which birds had been subjected, the lower the feed intake was in refeeding phase. 
Table 2. Performance of quails for meat production at 42 days old, which were submitted to feed restriction levels of $30 \%, 50 \%$ and $70 \%$ ad libitum intake from 15 to 35 days of age and refed from 36 to 42 days of age.

\begin{tabular}{|c|c|c|c|c|c|c|}
\hline \multirow{2}{*}{ Feed restriction levels } & \multicolumn{2}{|c|}{ FI (g/bird) } & \multicolumn{2}{|c|}{ WG (g/bird) } & \multicolumn{2}{|c|}{ FE $(\% /$ bird $)$} \\
\hline & $\mathrm{M}$ & $\mathrm{F}$ & $\mathrm{M}$ & $\mathrm{F}$ & $\mathrm{M}$ & $\mathrm{F}$ \\
\hline $70 \%$ restriction & 186,22 & 185,00 & 70,11 & 75,67 & 37,83 & 41,43 \\
\hline $50 \%$ restriction & 200,33 & 208,67 & 67,78 & 81,22 & 33,87 & 39,06 \\
\hline $30 \%$ restriction & 205,11 & 242,44 & 54,00 & 63,89 & 26,43 & 26,33 \\
\hline Ad libitum & 145,11 & 199,44 & 11,44 & 42,00 & 7,81 & 21,11 \\
\hline Mean & 184,19 & 208,89 & 50,83 & 65,69 & 0,265 & 0,320 \\
\hline $\mathrm{CV}(\%)$ & \multicolumn{2}{|c|}{8,97} & \multicolumn{2}{|c|}{9,85} & \multicolumn{2}{|c|}{12,22} \\
\hline \multicolumn{3}{|l|}{ Regression equation } & & $\mathrm{R}^{2}$ & \multicolumn{2}{|c|}{ Effect } \\
\hline \multicolumn{3}{|c|}{$\mathrm{FIm}=104,919+3,60859 \mathrm{DR}-0,0319697 \mathrm{DR}^{2}$} & & 0,76 & \multicolumn{2}{|c|}{ Quadratic } \\
\hline \multicolumn{3}{|c|}{ FIf $=71,7754+4,63874 \mathrm{DR}-0,0334 \mathrm{DR}^{2}$} & & 0,54 & \multicolumn{2}{|c|}{ Quadratic } \\
\hline \multicolumn{3}{|c|}{$\mathrm{CWGm}=51,7832+1,04485 \mathrm{DR}-0,0144816 \mathrm{DR}^{2}$} & & 0,96 & \multicolumn{2}{|c|}{ Quadratic } \\
\hline \multicolumn{3}{|c|}{$\mathrm{CWGf}=64,7877+0,701624 \mathrm{DR}-0,00938682 \mathrm{DR}^{2}$} & & 0,88 & \multicolumn{2}{|c|}{ Quadratic } \\
\hline \multicolumn{3}{|c|}{$\mathrm{FEm}=36,4484+0,186925 \mathrm{DR}-0,00473123 \mathrm{DR}^{2}$} & & 0,94 & \multicolumn{2}{|c|}{ Quadratic } \\
\hline \multicolumn{3}{|c|}{$\mathrm{FEf}=51,7435-0,316178 \mathrm{DR}$} & & 0,82 & \multicolumn{2}{|c|}{ Linear } \\
\hline
\end{tabular}

Coefficient of variation (CV); coefficient of determination $\left(\mathrm{R}^{2}\right)$; feed intake (FI); weight gain (WG); feed efficiency (FE); males (M); females (F); feed intake of males (FIm) and of females (FIf); compensatory weight gain of males (CWGm) and of females (CWGf); feed efficiency of males (FEm) and of females (FEf); levels of dietary restriction (DR).

Figure 1. Compensatory weight gain of males (CWGm) and females (CWGf) of quails for meat production at 42 days old, which were submitted to feed restriction of $30 \%, 50 \%$, and $70 \%$ ad libitum intake from 15 to 35 days old and refed from 36 to 42 days of age.

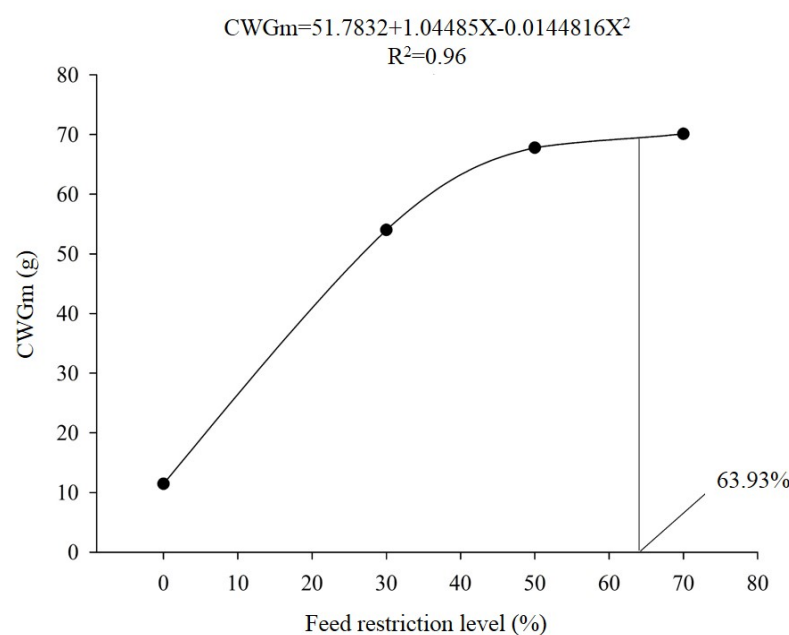

After 35 days of age, the body weight of females submitted to restriction and ad libitum feeding showed differences between 20 and 55\%, being lower for animals under more severe levels. After 42 days of age (refeeding), male and female under $70 \%$ DR presented body weights of 20 and

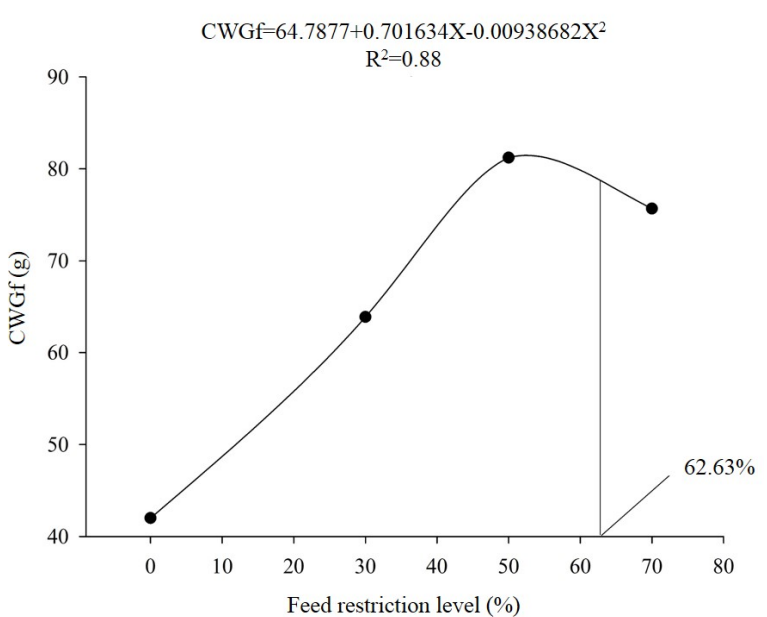

$35 \%$ lower than control, respectively. Under 50\% restriction, females reached a $10 \%$ lower body weight than those animals under $30 \%$ restriction. Moreover, males under 30\% restriction had a body weight equal to those of the control group - ad libitum (Table 3). 
Table 3. Mean body weight at 35 and 42 days of age for males and females of quails for meat production submitted to $30 \%, 50 \%$, and $70 \%$ feed restriction related to an ad libitum intake from 15 to 35 days of age and refed from 36 to 42 days old.

\begin{tabular}{lcccccc}
\hline \multirow{2}{*}{ Feed restriction levels } & \multicolumn{2}{c}{ BW (g/bird) at 35 days of age } & \multicolumn{2}{c}{ BW (g/bird) at 42 days of age } \\
\cline { 2 - 7 } & $\mathrm{M}$ & $\mathrm{F}$ & Mean & $\mathrm{M}$ & $\mathrm{F}$ & Mean \\
\hline 70\% restriction & 104,89 & 97,22 & 101,06 & 175,00 & 172,89 & 173,95 \\
$50 \%$ restriction & 130,89 & 124,56 & 127,73 & 198,67 & 246,52 & 222,60 \\
30\% restriction & 167,67 & 175,11 & 171,39 & 221,67 & 239,00 & 230,34 \\
Ad libitum & 209,67 & 223,56 & 216,62 & 221,11 & 265,56 & 243,34 \\
\hline Mean & 153,28 & 155,11 & 154,20 & 204,11 & 230,99 & 217,56 \\
\hline
\end{tabular}

Mean body weight (BW); males (M); females (F).

Compensatory weight gains of quail organs and carcass parts

Regarding CWG of organs, there was no significant interaction $(\mathrm{p}<0.05)$ during refeeding (from 36 to 42 days of age). However, there was a linear effect particularly for liver, small intestine and gizzard as dietary restriction increased from 15 to 35 days of age (Table 4).

Table 4. Compensatory weight gain of quail organs at 42 days of age which underwent feed restriction of 30\%, 50\%, and $70 \%$ ad libitum intake from 15 to 35 days old and refeeding from 36 to 42 days.

\begin{tabular}{lccccc}
\hline $\begin{array}{l}\text { Feed } \\
\text { restriction levels }\end{array}$ & Heart $(\mathrm{g})$ & Liver $(\mathrm{g})$ & SI $(\mathrm{g})$ & SIL $(\mathrm{cm})$ & Gizzard $(\mathrm{g})$ \\
\hline $70 \%$ restriction & 1,74 & 3,02 & 5,27 & 14,75 & 1,57 \\
$50 \%$ restriction & 0,91 & 2,06 & 3,22 & 6,42 & 1,23 \\
$30 \%$ restriction & 0,83 & 1,70 & 3,48 & 10,75 & 1,13 \\
Ad libitum & 0,44 & 0,96 & 2,03 & 7,83 & 0,28 \\
\hline Mean & 0,98 & 1,94 & 3,5 & 9,94 & 1,05 \\
\hline CV $(\%)$ & 111,75 & 47,84 & 42,53 & 9,71 & 60,40 \\
\hline Regression equation & & & $\mathrm{R}^{2}$ & \multicolumn{2}{c}{ Effect } \\
Liver =3,68354-0,0280234DR & & & 0,96 & \multicolumn{2}{c}{ Linear } \\
SI =6,03879-0,0405872DR & & & 0,83 & & Linear \\
Gizzard =2,15953-0,0177259DR & & & 0,93 & \\
\hline
\end{tabular}

Coefficient of variation (CV); coefficient of determination $\left(\mathrm{R}^{2}\right)$; small intestine (SI); small intestine length (SIL); levels of dietary restriction (DR).

CWG for parameters heart and small intestine length showed no significant difference among restriction levels of feeding. Furthermore, there was no significant interaction $(\mathrm{p}<0.05)$ between dietary restriction and gender for the parts of the carcass assessed (Table 5). On the other hand, a CWG linear increase $(p<0.05)$ was observed for wings, legs and leg quarters, back and chest of quails throughout refeeding period (36 to 42 days of age), according to the increase of feed restriction levels from 15 to 35 days of age.

\section{Body chemical composition and deposition}

Table 6 shows a significant difference $(\mathrm{p}<0.05)$ for the variables crude protein, water and fat, where fat presented an interaction between levels of feed restriction and gender. 
Table 5. Compensatory weight gain of carcass parts of quails for meat production at 42 days of age, which were subjected to feed restrictions of $30 \%, 50 \%$ and $70 \%$ ad libitum intake from 15 to 35 days old and refeeding from 36 to 42 days of age.

\begin{tabular}{lcccc}
\hline Feed restriction levels & Wings $(\mathrm{g})$ & Legs and legs quarters $(\mathrm{g})$ & Back $(\mathrm{g})$ & Chest $(\mathrm{g})$ \\
\hline $70 \%$ restriction & 4,01 & 13,13 & 11,86 & 27,53 \\
$50 \%$ restriction & 2,15 & 9,67 & 8,14 & 19,98 \\
$30 \%$ restriction & 1,77 & 7,15 & 3,93 & 19,47 \\
Ad libitum & 1,60 & 1,24 & 3,85 & 4,88 \\
\hline Mean & 2,38 & 7,80 & 6,95 & 17,97 \\
\hline CV $(\%)$ & 41,23 & 43,57 & 67,95 & 33,60 \\
\hline Regression equation & & & $\mathrm{R}^{2}$ & Effect \\
Wings $=4,34660-0,0314190 \mathrm{DR}$ & & & 0,71 & Linear \\
Legs and legs quarters $=18,2455-0,167178 \mathrm{DR}$ & & 0,99 & Linear \\
Back $=14,2721-0,117234 \mathrm{DR}$ & & & 0,83 & Linear \\
Chest $=37,0128-0,304779 \mathrm{DR}$ & & & 0,92 & Linear \\
\hline
\end{tabular}

Coefficient of variation $(\mathrm{CV})$; coefficient of determination $\left(\mathrm{R}^{2}\right)$; levels of dietary restriction (DR).

Table 6. Body chemical composition (fresh matter) of quails for meat production at 42 days old, which were subjected to feed restriction of $30 \%, 50 \%$ and $70 \%$ ad libitum intake from 15 to 35 days of age and refeeding from 36 to 42 days old.

\begin{tabular}{|c|c|c|c|c|c|}
\hline \multirow{2}{*}{$\begin{array}{l}\text { Feed } \\
\text { restriction levels }\end{array}$} & \multirow{2}{*}{$\mathrm{CP}(\% /$ bird $)$} & \multicolumn{2}{|c|}{$\mathrm{F}(\% / \mathrm{bird})$} & \multirow{2}{*}{ A (\%/bird $)$} & \multirow{2}{*}{$\mathrm{W}(\% / \mathrm{bird})$} \\
\hline & & $\mathrm{M}$ & $\mathrm{F}$ & & \\
\hline $70 \%$ restriction & 18,66 & 6,72 & 6,26 & 3,10 & 70,60 \\
\hline $50 \%$ restriction & 18,65 & 7,55 & 7,99 & 3,06 & 69,98 \\
\hline $30 \%$ restriction & 18,81 & 8,56 & 9,03 & 3,06 & 68,47 \\
\hline Ad libitum & 19,43 & 8,57 & 11,18 & 3,10 & 66,45 \\
\hline Mean & 18,89 & 7,85 & 8,61 & 3,05 & 68,88 \\
\hline CV $(\%)$ & 3,14 & & & 5,37 & 1,63 \\
\hline \multicolumn{2}{|c|}{ Regression equation } & & $\mathrm{R}^{2}$ & Effect & Interaction \\
\hline \multicolumn{2}{|c|}{$\mathrm{CP}=18,1862+0,0112343 \mathrm{DR}$} & & 0,17 & Linear & NS \\
\hline \multicolumn{2}{|c|}{$\mathrm{Fm}=6,15028+0,0271682 \mathrm{DR}$} & & 0,36 & Linear & $\mathrm{S}$ \\
\hline \multicolumn{2}{|c|}{$\mathrm{Ff}=4,322273+0,0686684 \mathrm{DR}$} & & 0,90 & Linear & $\mathrm{S}$ \\
\hline \multicolumn{2}{|c|}{$\mathrm{W}=72,6931-0,0611355 \mathrm{DR}$} & & 0,69 & Linear & NS \\
\hline
\end{tabular}

Coefficient of variation $(\mathrm{CV})$; coefficient of determination $\left(\mathrm{R}^{2}\right)$; crude protein $(\mathrm{CP})$; fat $(\mathrm{F})$; ashes $(\mathrm{A})$; water $(\mathrm{W})$; males $(\mathrm{M})$; females (F); fat for males (Fm) and for females (Ff); levels of dietary restriction (DR); significant (S); non-significant (NS).

Fat results displayed a linear behaviour for both males and females $(p<0.05)$. The higher the amount of feed provided, from 15 to 35 days of age, the greater the content of body fat found in females and in males at 42 days of age. It is noteworthy that females accumulated higher amounts of fat in the carcass than did the males.

Dietary restriction also influenced CP content, which increased linearly $(\mathrm{p}<0.05)$ in the carcasses as restriction decreased, until ad libitum feeding.
Likewise, body water rose linearly $(\mathrm{p}<0.05)$, but unlike $\mathrm{CP}$, the higher the feed restriction level, the higher the amount of water found in carcasses.

Table 7 presents a significant interaction ( $\mathrm{p}$ $<0.05$ ) between gender and restriction levels for protein deposition rate (PDR) and fat (FDR), as well as for CRE.

For males, PD and CRE showed a quadratic behaviour ( $p$ <.05) (PDm and CREm) during 
refeeding as a function of an interaction between gender and restriction levels from 15 to 35 days of age. The maximum estimates for PDm (38.48 g) and higher amount of CREm $(375.05 \mathrm{Kcal} / \mathrm{kg})$ were reached at restriction levels of $1.94 \%$ and $9.34 \%$, respectively (Figure 2).

Table 7. Chemical deposition of protein, fat, and energy retained in the carcass (fresh matter) of quails for meat production at 42 days old under feed restriction of $30 \%, 50 \%$ and $70 \%$ ad libitum intake from 15 to 35 days of age and refed from 36 to 42 days of age.

\begin{tabular}{|c|c|c|c|c|c|c|}
\hline \multirow{2}{*}{$\begin{array}{l}\text { Feed } \\
\text { restriction levels }\end{array}$} & \multicolumn{2}{|c|}{ PDR (g/bird) } & \multicolumn{2}{|c|}{ FDR (g/bird) } & \multicolumn{2}{|c|}{ CRE (kcal/kg/bird) } \\
\hline & M & $\mathrm{F}$ & M & $\mathrm{F}$ & M & $\mathrm{F}$ \\
\hline $70 \%$ restriction & 30,21 & 29,31 & 10,75 & 9,97 & 271,69 & 259,27 \\
\hline $50 \%$ restriction & 33,12 & 35,49 & 13,51 & 15,02 & 314,07 & 341,67 \\
\hline $30 \%$ restriction & 37,89 & 39,45 & 16,92 & 19,37 & 372,98 & 404,75 \\
\hline Ad libitum & 38,27 & 44,01 & 16,38 & 26,14 & 370,10 & 494,06 \\
\hline Mean & 34,87 & 37,07 & 14,39 & 17,62 & 332,21 & 374,94 \\
\hline CV (\%) & \multicolumn{2}{|c|}{3,03} & \multicolumn{2}{|c|}{11,67} & \multicolumn{2}{|c|}{5,46} \\
\hline \multicolumn{3}{|c|}{ Regression equation } & & $\mathrm{R}^{2}$ & \multicolumn{2}{|c|}{ Effect } \\
\hline \multicolumn{3}{|c|}{$\mathrm{PDm}=20,5362+0,366015 \mathrm{DR}-0,00186637 \mathrm{DR}^{2}$} & & 0,89 & \multicolumn{2}{|c|}{ Quadratic } \\
\hline \multicolumn{3}{|c|}{$\mathrm{PDf}=24,2124+0,163301 \mathrm{DR}$} & & 0,97 & \multicolumn{2}{|c|}{ Linear } \\
\hline \multicolumn{3}{|c|}{$\mathrm{FDm}=9,18001+0,0833498 \mathrm{DR}$} & & 0,56 & \multicolumn{2}{|c|}{ Linear } \\
\hline \multicolumn{3}{|c|}{$\mathrm{FDf}=3,28195+0,229485 \mathrm{DR}$} & & 0,93 & \multicolumn{2}{|c|}{ Linear } \\
\hline \multicolumn{3}{|c|}{$\mathrm{CREm}=134,176+5,31394 \mathrm{DR}-0,0293083 \mathrm{DR}^{2}$} & & 0,85 & \multicolumn{2}{|c|}{ Quadratic } \\
\hline \multicolumn{3}{|c|}{$\mathrm{CREf}=167,793+3,31431 \mathrm{DR}$} & & 0,96 & \multicolumn{2}{|c|}{ Linear } \\
\hline
\end{tabular}

Coefficient of variation (CV); coefficient of determination $\left(\mathrm{R}^{2}\right)$; protein deposition rate (PDR); fat deposition rate (FDR); carcass retained energy (CRE); male $(\mathrm{M})$; females (F); protein deposition in males (PDm) and in females (PDf); fat deposition in males (FDm) and in females (FDf); carcass retained energy in males (CREm) and in females (CREf); levels of dietary restriction (DR).

Figure 2. Body protein deposition (PDm) and carcass retained energy (CREm) in males of quails for meat production at 42 days of age under feed restriction of $30 \%, 50 \%$ and $70 \%$ ad libitum intake from 15 to 35 days old and refed from 36 to 42 days of age.
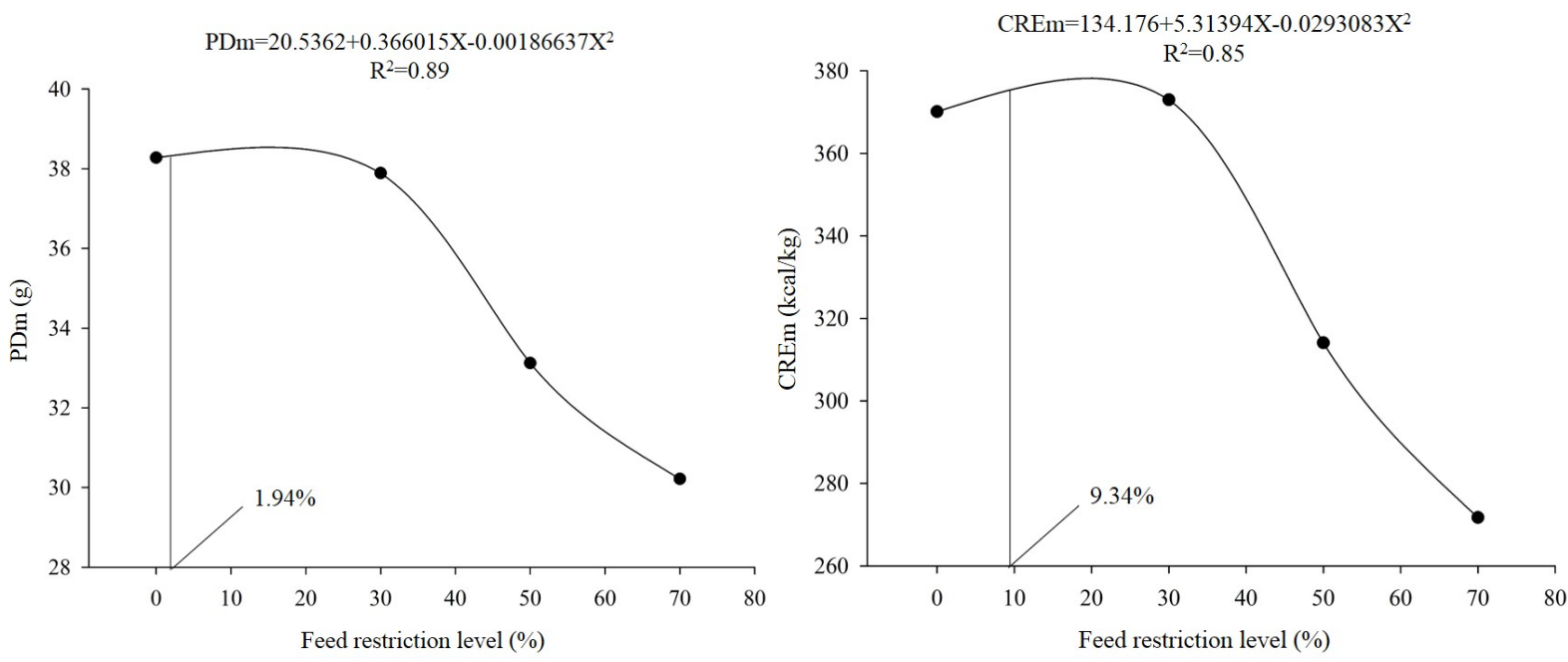
As for females, there was a linear increase ( $p$ $<0.05$ ) in PD (PDf), FD (FDf) and CRE (CREf) derived from a decrease in the level of feed restriction. The same linear effect was observed for fat deposition in males (FDm).

In general, females showed higher results for PDR, FDR and CRE when compared to males. However, for both genders and at lower dietary restriction, there were higher values for the same variables.

\section{Discussion}

During restriction period, weight gains were reduced, consequently, nutrient requirements for body maintenance varied. As a result, in refeeding, these variations enhanced efficiency in the use of nutrients provided by the diets for growth (LIPPENS et al., 2000). This outcome can be clearly visualized in this study. Here, the best results for weight gain and feed efficiency were obtained during refeeding of birds previously submitted to feed restriction. Confirming this statement, we may highlight that the maximum CWGs for males and for females were found in birds under restriction levels of $63.93 \%$ and $62.63 \%$, respectively.

As can be expected increasing body weights of birds should be proportional to larger organs, so that functional problems could be avoided. Therefore, in being refed, quails submitted to feed restrictions showed not only a CWG increase but also weight gains in organs and carcass parts. In this study, liver, small intestine, gizzard, wings, legs and leg quarters, back and chest CWG increased linearly in refeeding feed restriction was raised.

Interestingly, feed efficiency in males reached an optimal threshold at a high degree of feed restriction of $80.25 \%$. Yet for females, this effect was linear, i.e. the higher the restriction, the better the nutrient use efficiency for growth in refeeding period. This indicates that birds under dietary restriction have their nutritional needs altered as a survival strategy, which makes it more efficient later in the refeeding (LIPPENS et al., 2000).
Within the seven-day refeeding period, only quail males under the lowest feed restriction level (30\%) were able to achieve body weight similar to that of birds fed ad libitum (Table 3). In particular, we may highlight that the lower the feed restriction, the faster the bird recovers its body weight in refeeding. Robinson et al. (1992) observed that longer refeeding periods for broilers decreased the difference between weight gain of birds under restricted diet and those animals fed ad libitum, thus outlining possible advantages of this technique in poultry.

Animal body growth is established by deposition of four chemical components: protein, fat, water and ashes (EDWARDS JUNIOR et al., 1973; SAKOMURA et al., 2000). In quails, growth is fast until around 21 days of age, where deposition rates are higher for protein and water in the carcass. After this age, it slows down with an increase in fat deposition, mainly in the viscera, including in ovary (SILVA et al., 2009; GRIESER et al., 2015).

For most animals, increased body fat deposition is common with age, being related to a number of nutrients (proteins, carbohydrates, and fats) available for organism synthesis (SILVA et al., 2009). Such deposition is reduced when the capacity of consumption is only sufficient to maintain lean tissue growth. On the other hand, as the consumption capacity increases, fat deposition rises (REGINATTO et al., 2000). In addition, a larger volume of ingested feed can be poorly digested and absorbed by digestive tract due to a decrease in digestive enzyme efficiency (SAKOMURA et al., 2004).

However, protein deposition is controlled by animal genetics, being limited daily regardless of the diet (SILVA et al., 2009). According to Gonzáles and Sartori (2002), diet may increase protein in the carcass, or as stated by Ruts (2002), it decreases because in diets with deficient contents of amino acids essential to meet the nutritional requirements of animals, organism begins to catabolize body protein. The availability of nutrients in a diet changes the rates of lipogenesis, modifying body deposition of fat and protein (KESSLER et al., 2000). 
The greater the severity of dietary restrictions, the smaller the body fat content during refeeding. Sugeta et al. (2002) demonstrated similar findings to ours in an experiment with broiler chickens, in which animals remained under feed restriction from 8 to 14 days of age and were then fed ad libitum up to 42 days. These authors reported that birds under a $70 \%$ feed restriction showed a lower body fat content at 42 days compared to a control group fed $30 \%$ feed restriction.

Quail growth curves presented marked differences between genders, in which females had higher growth than did males (SILVA et al., 2009). Overall, this contrast in body weight starts around the third and fourth week of age, being attributed to the ovaries and liver of females (OGUZ et al., 1996). Males and females of quails for meat production can be differed in several respects, such as weight at maturity, composition and deposition rates of body chemical nutrients, varying according to the growth stage (GOUS et al., 1999). In this study, such differences between males and females interfered with the results regarding $\mathrm{FC}, \mathrm{WG}, \mathrm{EE}$, PDR, FDR, and CRE. Furthermore, we observed a significant interaction between both parameters (gender and feed restriction levels).

\section{Conclusion}

We can conclude that the level of quantitative dietary restriction provides an improvement in feed efficiency, increase in body weight gain and decrease for fat accumulated in the carcass during refeeding period of quails for meat production. As for gender, given the existing sexual dimorphism, females lost more body weight than did males, both under the same restriction, besides presenting higher protein and fat gains in the carcass and enhanced feed efficiency while refeeding.

\section{References}

ABREU, L. R. A.; BOARI, C. A.; PIRES, A. V.; PINHEIRO, S. R. F.; OLIVEIRA, R. G.; OLIVEIRA, K. M.; GONÇALVES, F. M.; OLIVEIRA, F. R. Influência do sexo e idade de abate sobre rendimento de carcaça e qualidade da carne de codornas de corte. Revista Brasileira de Saúde e Produção Animal, Salvador, v. 14, n. 1, p. 131-140, 2014.

ASSOCIATION OF OFFICIAL ANALYTICAL CHEMISTS - AOAC. Official methods of analysis. $15^{\text {th }}$ ed. Washington: Association of official analytical chemists, 1990.

AUCKLAND, J. N.; MORRIS, T. R. Compensatory growth in turkeys: effect of undernutrition on subsequent protein requirements. British Poultry Science, Edinburgh, v. 12, n. 1, p. 41-48, 1971.

DU PREEZ, J. J.; SALES, J. Growth rate of different sexes of the European quail (Coturnix coturnix). British Journal of Poultry Science, London, v. 38, n. 3, p. 314315, 1997.

EDWARDS JUNIOR, H. M.; DEMMAN, F.; ABOUASHOUR, A.; NUGARA, D. Influences of age, sex and type of dietary fat supplementation on total carcass and fatty acid composition. Poultry Science, Champaign, v. 52, n. 3, p. 934-948, 1973.

FONTANA, E. A.; WEAVER, W. D.; DENBOW, D. M.; WATKINS, B. A. Effect of early feed restriction on growth, feed conversion and mortality in broiler chickens. Poultry Science, Champaign, v. 71, n. 8, p. 1296-1305, 1992.

FRAGA, A. L.; MOREIRA, I.; FURLAN, A. C.; BASTOS, A. O.; OLIVEIRA, R. P.; MURAKAMI, A. E. Lysine requirement of starting barrows from two genetic groups fed on low crude protein diets. Brazilian Archives of Biology and Technology, Curitiba, v. 51, n. 1, p. 49-56, 2008.

GONZÁLES, E.; SARTORI, J. R. Crescimento e metabolismo muscular. In: MACARI, M.; FURLAN, R. L.; GONZÁLES, E. (Ed.). Fisiologia aviária aplicada a frangos de corte. 2. ed. Funep: Jaboticabal, 2002. p. 375. p. 279-298.

GOUS, R. M.; MORAN JUNIOR, E. T.; STILBORN, H. R.; BRADFORD, G. D.; EMMANS, G. C. Evaluation of the parameters needed to describe the overall growth, the chemical growth, and the growth of feathers and breast muscles of broilers. Poultry Science, Champaign, v. 78, n. 6 , p. 812-821, 1999.

GRIESER, D. O.; MARCATO, S. M.; FURLAN, A. C.; ZANCANELA, Z.; TON, A. P. S.; BATISTA, E.; PERINE, T. P.; POZZA, P. C.; SAKOMURA, N. C. Comparison of growth curve parameters of organs and body components in meat- (Coturnix coturnix coturnix) and laying-type (Coturnix coturnix japonica) quail show interactions between gender and genotype. British Poultry Science, Edinburgh, v. 56, n. 1, p. 6-14, 2015. 
KESSLER, A. M.; SNIZEK, P. N.; BRUGALLI, I. Manipulação da quantidade de gordura na carcaça de frangos. In: CONFERÊNCIA APINCO DE CIÊNCIA E TECNOLOGIA AVÍCOLAS, 2000, Campinas. Anais... Campinas: Facta, 2000. p. 107-133.

LANA, G. R. Q.; ROSTAGNO, H. S.; DONZELE, J. L.; LANA, Â. M. Q. Efeito de programas de restrição alimentar sobre o desempenho produtivo e econômico e a deposição de gordura na carcaça de frangos de corte. Revista Brasileira de Zootecnia, Viçosa, MG, v. 28, n. 6, p. 1302-1309, 1999.

LIPPENS, M.; ROOM, G.; DE GROOTE, G.; DECUYPERE, E. Early and temporary quantitative food restriction of broiler chickens. 1. Effects on performance characteristics, mortality and meat quality. British Poultry Science, Edinburgh, v. 41, n. 3, p. 343-354, 2000.

OGUZ, I.; ALTAN, O.; KIRKPINAR, F.; SETTAR, P. Body weights, carcass characteristics, organ weights, abdominal fat and lipid content of liver and carcass on two lines of japanese quail (Coturnix coturnix japonica), unselected and selected for four week body weight. British Poultry Science, Edinburgh, v. 37, n. 3, p. 579588, 1996.

OMOSEBI, D. J.; ADEYEMI, O. A.; SOGUNLE, M. O.; IDOWU, O. M. O.; NJOKU, C. P. Effects of duration and level of feed restriction on performance and meat quality of broiler chickens. Archivos de Zootecnia, v. 63, n. 244, p. 611-621, 2014.

OSBOURN, D. F.; WILSON, P. N. Effects of different patterns of allocation of a restricted quantity of food upon the growth and development of cockerels. The Journal of Agricultural Science, Cambridge, v. 54, n. 2, p. 278-289, 1960.

PLAVINIK, I.; HURWITZ, S. The performance of broiler chicks during and following a severe feed restriction at early age. Poultry Science, Champaign, v. 64, n. 2, p. 348-355, 1985.

REGINATTO, M. F.; RIBEIRO, A. M. L.; KESSLER, A. M.; PENZ JUNIOR, A.; KRABBE, E. L. Efeito da energia, relação energia: proteína e fase de crescimento sobre o desempenho e composição de carcaça de frangos de corte. Revista Brasileira de Ciência Avícola, Campinas, v. 2, n. 3, p. 229-237, 2000.

ROBINSON, F. E.; CLASSEN, H. L.; HANSON, J. A.; ONDERKA, D. K. Growth performance, feed efficiency and the incidence of skeletal and metabolic disease in full-fed and feed restricted broiler and roaster chickens. Journal of Applied Poultry Research, Athens, v. 1, n. 1, p. 33-41, 1992.

ROSA, P. S.; ÁVILA, V. S.; JAENISCH, F. R. F. Restrição alimentar em frangos de corte: como explorar suas potencialidades. Concórdia: EMBRAPA Suínos e Aves, 2000. 4 p.

ROSTAGNO, H. S.; ALBINO, L. F. T.; DONZELE, J. L.; GOMES, P. C.; OLIVEIRA, R. F.; LOPES, D. C.; FERREIRA, A. S.; BARRETO, S. L. T.; EUCLIDES, R. F. Tabelas brasileiras para aves e suínos: composição de alimentos e exigências nutricionais. 2. ed. Viçosa, MG: UFV, Departamento de Zootecnia, 2011. 252 p.

RUTZ, F. Metabolismo intermediário. In: MACARI, M.; FURLAN, R. L.; GONZÁLES, E. (Ed.). Fisiologia aviária aplicada a frangos de corte. 2. ed. Funep: Jaboticabal, 2002. p. 175-186.

SAKOMURA, N. K. Modeling energy utilization in broiler breeders, laying hens and broilers. Revista Brasileira de Ciência Avícola, Campinas, v. 6, n. 1, p. 1-11, 2004.

SAKOMURA, N. K.; LONGO, F. A.; FERRAUDO, A. S.; FIGUEIREDO, A. N.; SILVA, R. Desenvolvimento corporal de penas e da deposição de tecido magro e de gordura em frangos de corte. Revista Brasileira de Ciência Avícola, Campinas, v. 2, n. 1, p. 34-34, 2000. Suplemento 2.

SAKOMURA, N. K.; LONGO, F. A.; RABELLO, C. B.; WATANABE, K.; PELÍCIA, K.; FREITAS, E. R. Efeito do nível de energia metabolizável da dieta no desempenho e metabolismo energético de frangos de corte. Revista Brasileira de Zootecnia, Viçosa, MG, v. 33, n. 6, p. 1758-1767, 2004.

SAKOMURA, N. K.; ROSTAGNO, H. S. Métodos de pesquisa em nutrição de monogástricos. Jaboticabal: Funep, 2007. 283 p.

SILVA, J. H. V.; COSTA, F. G. P.; GOUlART, C. C. Tabela de exigência nutricional de codornas Japonesas e Europeias: bases para nutrição de codornas. 2. ed. Jaboticabal: Fundação de Apoio à Pesquisa, Ensino e Extensão, FUNCEP, 2009. 107 p.

STATISTICALANALYSIS SYSTEM - SAS. System for microsoft windows. Version Release 8.2. for Windows. Cary: Universitat Autònoma de Barcelona, 2001. CDROM.

SUGETA, S. M.; GIACHETTO, P. F.; MALHEIROS, E. B.; MACARI, M.; FURLAN, R. L. Efeito da restrição alimentar quantitativa sobre o ganho compensatório e composição da carcaça de frangos. Pesquisa Agropecuária Brasileira, Brasília, v. 37, n. 7, p. 903-908, 2002.

YU, M. W.; ROBINSON, F. E.; CLANDINI, M. T.; BODNAR, L. Growth and body composition of broiler chickens in response to different regimens of feed restriction. Poultry Science, Champaign, v. 69, n. 12, p. 2074-2081, 1990. 